\title{
Mendesain Pembangunan Berdasar Perspektif Sosial Budaya
}

\author{
Mudjahirin Thohir \\ Fakultas Ilmu Budaya, Universitas Diponegoro \\ mudjahirinthohir@ymail.com
}

\begin{abstract}
The development is a deliberate design of cultural change to improve peple's live. Change in people knowledge, behavior, or its facilities. However, the people who were the target of the development, not necessarily accept it. Why? It is related to how the strategy to bringing together the understanding between goverment, people, and the development executor.
\end{abstract}

Keywords: development, perspective, people, cultural, understanding.

\section{Intisari}

Pembangunan adalah suatu desain perubahan kebudayaan yang disengaja terhadap kehidupan masyarakat, baik perubahan pada tataran ide, kegiatan, maupun fasilitasi untuk menjadikan kehidupan lebih baik. Namun demikian, masyarakat yang menjadi sasaran atau sebagai pengguna pembangunan itu, tidak dengan sendirinya menerimanya. Hal ini terkait pada bagaimana strategi mempertemukan pemahaman antara pemerintah, rakyat, dan lembaga atau owner yang diberi kewenangan membangunnya.

Kata kunci : pembangunan, perspektif, masyarakat, budaya, pemahaman.

\section{Pendahuluan}

Ada adagium bahwa dalam kehidupan di dunia ini, semuanya akan berubah. Yang tidak berubah adalah perubahan itu sendiri. Jika demikian halnya, maka perubahan adalah keniscayaan. Keniscayaan perubahan itu, berdampak kepada masyarakat manusia secara tidak sama. Dalam satu sisi, berdampak negatif, tetapi dalam sisi yang lain berdampak positif. Negatif atau positifnya dampak dari perubahan, terkait dengan kesiapan kita sendiri. Dalam hal ini, ada empat kategori masyarakat manusia mensikapi perubahan. Pertama, pasif bahkan apatis. Persetan dengan perubahan. Bukankah hidup itu bagaikan air, mengalir. Kedua, reaktif, yakni baru (akan) bereaksi ketika perubahan itu sudah datang di depan pintu rumah. Ketiga, adalah bersikap antisipatif. Artinya, sudah mengantisipasi kemungkinan terjadinya perubahan. 
Keempat, justru ikut proaktif melakukan perubahan itu sendiri. Tiga kelompok yang pertama, termasuk dalam kategori merespon atau menanggapi terhadap desakan dari luar, sementara kelompok keempat justru menjadi agent perubahan.

Jika salah satu dari penyebab perubahan dimaksud terkait dengan pembangunan teknologi, maka pertanyaannya ialah bagaimana pembangunan teknologi itu hadir dan dihadirkan untuk meningkatkan kualitas kehidupan masyarakat manusia Indonesia itu sendiri? Tulisan ini akan mengkaji pembangunan teknologi dalam perspektif sosial budaya.

Pembangunan teknologi dilihat dari perspektif sosial budaya artinya bahwa segala sesuatu (dalam hal ini pembangunan teknologi) dilihat dari sisi kesiapan masyarakat terhadap pembangunan dimaksud termasuk kebudayaan masyarakat seperti apa yang harus dipersiapkan sehingga adaptif terhadap perubahan. Untuk melukiskan adaptabilitas masyarakat terhadap perubahan (pembangunan teknologi), akan saya ajak melihat dan membandingkan dengan dua Negara Asia yakni Korea Selatan dan Jepang.

Pada tahun 1960-an, Ghana dan Korea Selatan, adalah dua negara yang memiliki produk domestik bruto (PDB) per kapita setara. Ekonomi mereka, samasama ditupang oleh produk, manufakturing, dan jasa primer. Mereka juga menerima bantuan ekonomi dari negara donor dalam jumlah yang seimbang. Tetapi tiga puluh tahun kemudian, yakni tahun 1990-an, Korea Selatan sudah menjadi raksasa industri dengan ekonomi terbesar ke-4 di dunia. Korsel telah berhasil membangun perusahaan-perusahaan multinasional, ekspor mobil, alat elektronik, dan barangbarang canggih hasil pabrik lainnya dalam jumlah besar. Akibat dari itu semua, pendapatan penduduk per kapita, mendekati Yunani. Sementara Ghana, tidak ada perubahan yang berarti. Maka wajar kalau PDB Korsel, lima belas kalinya lebih besar dari Ghana.

Bagaimana menjelaskan perbedaan yang luar biasa dalam perkembangan ini? Banyak faktor yang berperan. Tetapi yang jelas, budaya memainkan peran besar. 
Orang Korea Selatan menghargai hidup hemat, investasi, kerja keras, pendidikan, organisasi, dan disiplin ${ }^{1}$

Jauh sebelum Korea Selatan melesat jauh sebagai negara kaya, Jepang telah lebih dahulu menjadi negara yang luar biasa dahsyat. Negara yang pernah dibom atom oleh Amerika Serikat itu, justru bangkit bersama budayanya. Bagaimana caranya? Mereka mempekerjakan tenaga ahli dan teknisi asing (untuk disadap ilmunya), sembari mengirimkan wakil-wakil Jepang ke luar negeri untuk membawa laporan kemajuan Eropa dan Amerika. Intelijen semacam ini menjadi dasar bagi pilihan yang diambil. Ini mencerminkan pertimbangan yang hati-hati dan luwes akan keunggulan komparatif. Model pertama militer Jepang ialah (meniru) tentara Perancis. Tetapi setelah tentara Perancis dikalahkan oleh Prusia (1870-1), bangsa Jepang dengan segera memutuskan untuk belajar soal militer kepada Jerman.

Tidak ada kesempatan belajar yang disia-siakan. Bulan Oktober 1871, delegasi Jepang (tingkat tinggi) menyertakan Okuba Tomishi bepergian ke Amerika Serikat dan Eropa. Mengunjungi pabrik, pengecoran baja, galangan kapal, pabrik senjata, jalan kereta api, dan terusan. Setelah dua tahun kemudian (September 1873), para delegasi Jepang itu telah merasa mendapat pelajaran yang melimpah. Dan untuk selanjutnya, mereka dengan patriot nasionalismenya, berantusias mengubah negerinya. Jepang mesti bergegas (bandingan dengan kunjungan pejabat dan DPR RI yang pergi ke luar negeri).

Untuk memulainya, negara Jepang membangun cabang-cabang industri yang sudah mereka kenal, terutama pabrik sutra dan katun, serta membangun pabrik pemprosesan makanan pokok yang kebal dari peniruan luar negeri, seperti: sake, miso, dan kecap. Dari tahun 1877 - 1900 (13 tahun kemudian) - Jepang memulai generasi pertama industrialisasi. Industri makanan tumbuh sebesar $40 \%$, dan industri tekstil tumbuh $35 \%$.

Jepang tidak berhenti sampai di sini. Mereka bertekad untuk tidak sekedar menghasilkan barang-barang konsumen, tetapi Jepang ingin memiliki ekonomi

\footnotetext{
${ }^{1}$ Huntington, Samuel P. 2006. "Budaya Punya Andil", dalam Kebangkitan Peran Budaya. (Harrison, L.E \& Huntington, S.P. eds). Jakarta: LP3ES. Hlm. Xiii - xviii.
} 
modern. Ini berarti harus menguasai industri berat seperti: membangun mesin, motor, kapal, lokomotif, jaringan kereta, pelabuhan, dan galangan kapal. Pemerintah memainkan peran penting. Membiayai pengintaian di luar negeri, mendatangkan para ahli dari luar negeri, membangun instalasi, dan menyubsidi usaha perdagangan. Selain itu, bakat dan determinasi para patriot Jepang, siap mengganti karier demi perjuangan nasional. Jepang meningkatkan kualitas para pekerja, terutama para tukang yang terampil, dengan kecakapan yang terasah dan sikap yang terbentuk oleh tim kerja yang akrab dan pembimbingan di bengkel-bengkel pertukangan.

Jika negara-negara lain mengirimkan orang-orang muda (termasuk Indonesia) ke luar negeri untuk belajar cara-cara yang baru dan setelah mendapatkan apa yang dicari mereka umumnya tidak mau kembali ke negara asalnya, tidak demikian halnya dengan anak-anak muda Jepang. Ekspatriot Jepang pulang kembali ke negerinya. Jika negera-negara lain mendatangkan teknisi asing untuk mengajari rakyatnya, Jepang pada umumnya mengajar diri mereka sendiri. Jepang memodifikasinya, membuatnya lebih baik, membuatnya sendiri. ${ }^{2}$

Jepang dan Korea Selatan telah mewujudkan kemakmuran rakyatnya (sekaligus negaranya). Kemakmuran itu, ditentukan oleh produktivitas yang dengannya negara menggunakan sumber daya manusia, modal, dan alamnya. Produktivitas tadi, membentuk tingkat upah dan pengembalian modal yang terjaga. Produktivitas adalah basis dari "daya saing". Produktivitas tergantung pada nilai produk dan jasa yang dihasilkan oleh perusahaan-perusahaan, misalnya adanya kualitas dan keunikan, serta efesiensi saat berproduksi.

Tulisan ini akan mengkaji bagaimana seharusnya pembangunan dalam hal ini, pembangunan PLTN (pusat listrik tenaga nuklir) yang direncanakan dibangun di daerah pesisir Jepara direncanakan berdasarkan pada pendekatan kebudayaan.

\footnotetext{
${ }^{2}$ Lihat Landes, David. 2006. "Hampir Semua Perbedaan Datang dari Budaya", dalam Harrison, L.E \& Huntington, S.P (eds) hlm: 27 - 43).
} 


\section{Metode}

Tulisan ini didasarkan pada refleksi atas studi lapangan pada masyarakat pesisir utara Jawa (Jepara) atas kasus rencana pembangunan PLTN yang ternyata harus ditunda tanpa diketahui kapan akan dimulai lagi. Setelah dilakukan kegiatan fgd (focused group discussion) kepada sejumlah warga, ditemukan jawaban yang terbelah ke dalam dua pensikapan, yaitu sebagian menyetujui karena melihat sisi positif dari pembangunan PLTN itu sendiri. Sedang sebagian yang lain menolak lantaran kekhawatiran kalau terjadi ekses teknologis yang berdampak negatif, seperti kalau terjadi kebocoran bangunan PLTN itu sendiri. Namun demikian, tulisan ini lebih memetakan secara kognitif berdasarkan pada dalil-dalil referensial yang relevan.

\section{Hasil}

\section{Sumber-sumber Kemakmuran}

Dulu, paradigma kemakmuran dalam sebuah negara secara luas dilihat sebagai hasil pemilikan sumber daya alam (SDA) seperti lahan, hasil tambang, atau pekerja dalam jumlah banyak, yang memberi negara itu sebuah keunggulan komparatif atas negaranegara lain yang sumber dayanya kurang menguntungkan. Tetapi, dalam ekonomi global modern, perusahaan-perusahaan bisa mendapatkan sumber-sumber dari lokasi manapun dengan murah dan efektif, sehingga membuat sumber-sumber itu sendiri menjadi kurang bernilai. Pekerja murah misalnya, ada di mana-mana, sehingga memiliki pekerja dalam jumlah banyak bukanlah sesuatu yang hebat maupun suatu sumber keuntungan. Apalagi dengan biaya transportasi dan komunikasi yang turun secara cepat. Ini terbukti bahwa sebuah perusahaan di Hongkong atau di Cile misalnya, masih bisa menjadi mitra dagang utama Amerika atau Eropa. Dengan demikian, dasar kemakmuran atas keunggulan komparatif, telah tergusur oleh keunggulan kompetitif yang bersandar pada produktivitas yang hebat dalam memadukan sumber-sumber daya untuk menciptakan produk dan jasa yang bernilai. Negara-negara yang meningkatkan standar hidup adalah mereka yang perusahaanperusahaannya menjadi lebih produktif melalui pembangunan sumber-sumber keunggulan kompetitif yang lebih canggih yang berdasarkan pada pengetahuan, 
investasi, wawasan, dan inovasi. ${ }^{3}$ Sebaliknya, negara yang hanya memiliki penduduk dalam jumlah besar tetapi tidak kompetitif, nasibnya seperti Indonesia dewasa ini: melakukan eksport tenaga kerja (umumnya unskill Labour) seperti TKI/TKW, baik yang masuk kategori legal atau tidak legal.

Keunggulan kompetitif digerakkan oleh apa yang disebut budaya produktif. Tetapi umumnya negara berkembang seperti Indonesia, justru lemah dari sudut ini. Dengan kata lain, budaya (tidak produktif) itu tetap bertahan dalam masyarakat kita. Mengapa?

Jawabannya, pertama, apa yang diperlukan untuk menjadi makmur berkaitan dengan bagaimana bersikap. Sikap itu sendiri dipengaruhi oleh cara kita memberi makna terhadap arti hidup, dan arti kerja. "Jika hidup (usia manusia itu pendek), maka pertanyaan yang patut direnungkan ialah: "apakah karena hidup di dunia ini pendek, maka apa gunanya beretos kerja tinggi? Atau justru sebaliknya: yakni karena hidup (di dunia) ini pendek, maka bagaimana memaksimalisasi kinerja?

Kedua, perusahaan-perusahaan di negara-negara berkembang (seperti Indonesia) sering bertindak oportunis dan tidak berencana berdasarkan jangka panjang. Kenyataan demikian, seringkali terkait dengan suatu lingkungan di mana kebijakan-kebijakan pemerintah, tidak stabil dan tidak dapat diramalkan. Ingat ungkapan: Ganti menteri, ganti aturan. Inilah dosa pemerintah terhadap rakyatnya sendiri.

Ketiga, adanya mentalitas umum masyarakat kita yang kurang responsif terhadap perubahan atau pembangunan. Masih banyak di antara kita yang lebih suka melihat perubahan atau pembangunan dari sisi kesulitan yang akan ditemui daripada peluang yang memungkinkan yang bisa dicapai, mengingatkan saya mengenai sikap kaum pemenang yang berbeda secara diametral dengan sikap kaum pecundang yang kalah dan seringkali gagal. Kaum pemenang melihat pada setiap kesulitan, diyakini pasti ada jalan keluar. Tetapi kaum pecundang akan melihat sebaliknya. Kaum pecundang tidak siap menghadapi kesulitan dan tidak siap pula berkompetisi. Jika di

\footnotetext{
${ }^{3}$ Lihat Porter, Micahael E. 2006. "Sikap, Nilai, Kepercayaan, dan Makroekonomi Kemakmuran", dalam Harrison, L.E \& Huntington, S.P (eds) hlm: $44-64$.
} 
hadapannya terbuka peluang dan kemudahan, akan dilihat bahwa di balik peluang dan kemudahan itu pasti akan ditemui kesulitan. Jadi, orientasinya ialah menghindari kesulitan, bukan menyelesaikan persoalan sesulit apapun.

Dari sinilah lalu, kita menentukan arah dan barometer diri ke depan. Yang jelas, kesuksesan tidak akan datang dan mendatangi pemuda-pemuda yang hanya bisa statik, atau reaktif, tetapi kesuksesan itu adalah milik kaum muda yang antipatif, lebih-lebih yang pro-aktif terhadap perubahan itu sendiri.

\section{Pembangunan Peradaban}

Proses pembangunan teknologi yang berdampak kepada pengembangan dan kemakmuran ekonomi merupakan serangkaian keputusan berkelanjutan yang memihak investasi, persaingan, dan inovasi. Di dalam prosesnya, pembangunan seperti itu, hampir selalu memunculkan berbagai godaan. Dari sinilah perlunya kita terutama para pejabat, penguasa, dan para pengambil keputusan, untuk membekali sistem nilai yang bisa bertahan dari godaan. Sistem nilai itu adalah nilai instrinsik, bukan nilai instrumental.

Sistem nilai instrinsik adalah nilai-nilai yang kita junjung tanpa menghiraukan manfaat jangka pendek atau yang bercorak materi, seperti kejujuran dan patriotisme. Dengan patriotisme itulah beribu-ribu orang siap meninggal untuk mempertahankan negara mereka sepanjang sejarah. Di antara nilai intrinsik yang lain yang bercorak non-ekonomi adalah keselamatan, kelangsungan hidup, keamanan, keunggulan, prestise, atau bahkan nasionalisme. Sebaliknya adalah nilai instrumental. Sebuah nilai menjadi instrumental ketika kita menyokongnya karena nilai itu secara langsung bermanfaat, seperti meningkatnya kekayaan. Jabatan dan kekuasaan (jika tidak tahan dengan godaan) lantas dijadikan pijakan untuk meraup keuntungan, dengan mengabaikan profesionalitas dan moralitas.

Agar nilai-nilai instrinsik itu tetap bisa bertahan, maka ia harus tetap menjadi nonekonomi dan proekonomi pada saat yang bersamaan. Contoh sederhananya, pekerja masjid harus mengerahkan segala kemampuannya sebagaimana tanggungjawabnya atas pekerjaan yang diamanatkan kepadanya, tetapi tidak lalu karena alasan kerja untuk tempat ibadah - mereka lantas tidak dibayar. Dengan 
demikian, pembangunan ekonomi termasuk kerja perlu dilihat sebagai sebuah proses budaya. Nilai-nilai yang masuk ke dalam wilayah budaya disebut etika. Di sinilah agama dan pendidikan memiliki peran pembangunan sekaligus peran yang terkait dengan kualitas atau mutu kehidupan masyarakat manusia.

\section{Bagaimana Pembangunan Teknologi Dirumuskan dan Diproses?}

Pembangunan dapat dilihat sebagai serangkaian upaya yang direncanakan dan dilaksanakan oleh pemerintah, badan-badan atau lembaga-lembaga internasional, nasional, atau lokal, yang terwujud dalam bentuk-bentuk kebijaksanaan, program, atau proyek, yang secara tersurat atau tersirat dimaksudkan untuk terciptanya kualitas kehidupan warga masyarakat ke arah yang lebih baik atau lebih sejahtera daripada sebelum adanya pembangunan tersebut. Dengan demikian, dalam batas-batas tertentu pembangunan bisa dimaknai sebagai upaya-upaya penyiapan dan kesiapan pengubahan secara terencana kebudayaan dari masyarakat yang dibangun. ${ }^{4}$

Dalam konteks seperti itu, pemerintah dalam satu sisi memiliki kewajiban untuk melakukan serangkaian pembangunan untuk dan demi perbaikan kualitas kehidupan rakyat, sementara rakyat memiliki hak-hak untuk mendapatkan pelayanan pemerintah seperti halnya pembangunan itu sendiri. Namun demikian, pembangunan di Indonesia tidak selalu berjalan secara baik sesuai dengan perencanaan awal, dan pelaksanaan serta hasil dari pembangunan itu sendiri bisa jadi kurang memberi nilai kemanfaatan secara optimal. Hal ini bisa terjadi sebagai akibat antara lain munculnya kepentingan berbagai pihak yang secara sengaja atau tidak sengaja, membelokkan arah dari pembangunan dimaksud maupun oleh karena adanya respons-respons yang bercorak negatif dari elemen-elemen masyarakat oleh karena ketidakpahaman maupun kecurigaan oleh karena dalam proses-proses pembangunan itu rakyat sama sekali tidak dilibatkan. Kalau demikian halnya, maka pembangunan terutama pembangunan yang memiliki dampak langsung terhadap perubahan kehidupan masyarakat manusia - dalam prosesnya perlu didialogkan untuk dicarikan titik temu, komitmen bersama. Selebihnya dari itu adalah pengkawalan secara

\footnotetext{
${ }^{4}$ Suparlan, Parsudi. 1986. "Kebudayaan dan Pembangunan", dalam MEDIA IKA, no. 14, th 11, Hlm. $106-135$.
} 
berkesinambungan sehingga keseluruhannya itu berjalan dan dijalankan sesuai dengan titik-temu dan komitmen yang telah disepakatnya itu. Dari sinilah kita lalu mengenal istilah "model untuk pembangunan" dan "model dari pembangunan".

"Model-Untuk Pembangunan" adalah perspektif dan paradigmatik yang menjadi dan dijadikan landasan desain atau titik tolak untuk pembangunan itu sendiri. Perspektif pembangunan menjelaskan kepada dari sudut kepentingan siapa pembangunan itu perlu diujudkan. Paradigmatik menyangkut kepada pandangan dan cara kita menjelaskan dan memahamkan mengenai esensi pembangunan (what), mengapa (why) dipilih, dan bagaimana (how) mewujudkan pilihannya itu. Sedang desain pembangunan adalah rancangan atau blue-print pembangunan yang bertolak dan bergerak dari perspektif dan paradigmatik pembangunan yang telah disepakati oleh berbagai pihak yang terkait ke dalamnya, misalnya: pemerintah -- owner masyarakat ${ }^{5}$.

Sedang apa yang saya maksud dengan "Model Dari Pembangunan" adalah implementasi proses-proses pembangunan yang bergerak-dari dan bergerak-atas blueprint pembangunan yang telah disepakti berlakunya. Dengan demikian maka pembangunan dilihat dari perspektif sosial budaya adalah proses negosiasi dari sejumlah pihak dalam kerangka kepentingan perubahan yang disengaja guna peningkatan kualitas kehidupan itu sendiri. Suatu proses negosiasi yang berkesinambungan seirama dengan tahapan-tahapan pembangunan yang dilalui.

Sebagai suatu proses negosiasi maka terdapat sifat-sifat yang hampir pasti menyertainya yaitu "ketegangan" dan "titik temu". Dalam konteks seperti inilah

\footnotetext{
${ }^{5}$ Yang dimaksud pemerintah di sini adalah pihak eksekutif, legislative (dan yudikatif) dari tingkat pusat sampai ke daerah. Pemerintahlah yang menjadi pihak penentu utama terhadap perlu tidaknya pembangunan. Owner adalah pihak-pihak rekanan yang menghubungi dan dihubungi oleh pemerintah untuk terlibat mewujudkan pembangunan itu sendiri. Mereka itu bisa investor (dalam dan luar negeri), para pengusaha, para konsultan tenaga ahli, dsb. Sedang masyarakat di sini bisa masyarakat (rakyat) dalam arti luas, tetapi terutama adalah masyarakat di daerah yang terkait dengan kepentingan pembangunan. Di dalam masyarakat itu, terdapat simpul-simpul yang menjadi dan seringkali berperan sebagai representator kepentingan masyarakat, seperti tokoh-tokoh masyarakat, tokoh agama, tokoh intelektual dan sejenisnya. Dari segi kelembagaan yang seringkali dan seharusnya membahasakan "suara rakyat" adalah DPR(D), Orsospol, lsm, dan sejenisnya. Lembaga-lembaga lain seperti pers, dan lembaga-lembaga penelitian, seperti puslit sosbud lemlit undip, perlu ditempatkan dan menempatkan diri sebagai fasilitor yakni menfasilitasi untuk dapat bertemu, mempertemukan, dan mencarikan titik temu dalam berbagai kepentingan: masyarakat - pemerintah - owner.
} 
pemberian informasi secara fair, duduk sama rendah - berdiri sama tinggi - dan dibalut dengan perasaan saling belajar menghormati dan dihormati - merupakan suatu kondisi sine qua non. Sebaliknya jika mengabaikan hal-hal seperti itu, akan mudah memunculkan sikap prejudice, dan like-dislike.

Dengan kata lain, suatu perencanaan pembangunan -- dalam satu sisi -merupakan pewacanaan, pendiskusian, pengwujudan keinginan dan kebutuhan perubahan ke arah yang lebih baik dalam situasi ketegangan yang sengaja dipelihara secara bertanggungjawab, dewasa, dan berkesantunan, dan dalam sisi yang lain dialog dan diskusi yang dalam hal-hal tertentu bisa berada dalam kondisi ketegangan - perlu dijaga keseimbangannya guna menemukan titik temu antara pihak-pihak yang terkait di dalamnya.

Jika diskemakan proses negosiasi dan titik temu antara: pemerintah-- owner dan masyarakat adalah sebagai berikut:

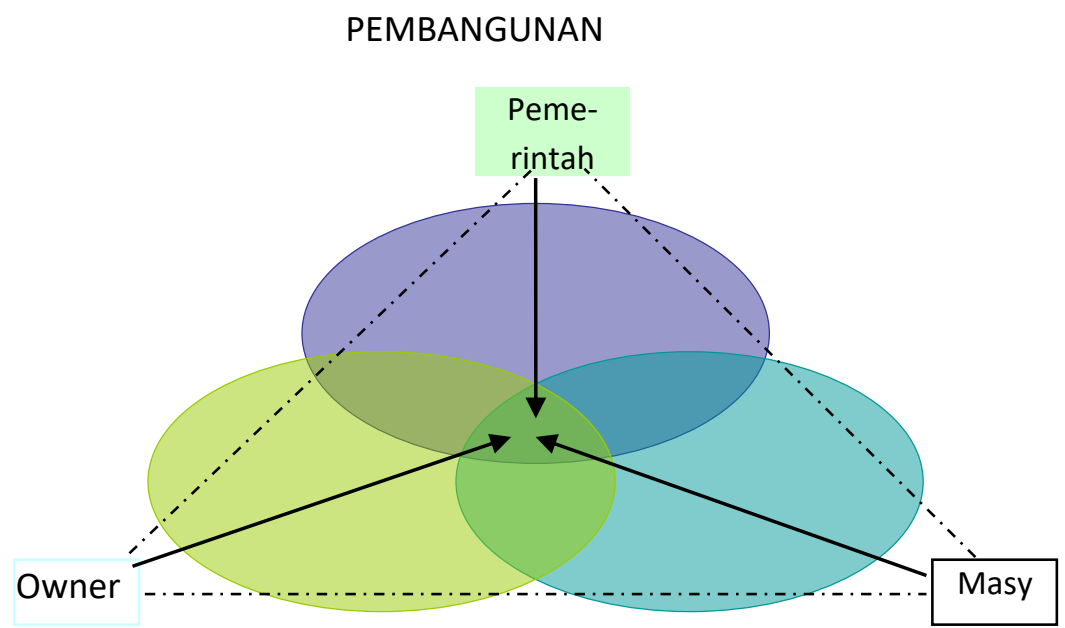

Negosiasi dalam satu sisi ( garis: - - -) dan upaya mencapai titik temu dalam sisi yang lain (garis: $\rightarrow$ ) merupakan keniscayaan dari suatu proses pembangunan yang seharusnya perlu dipelihara, bukan dinafikan atau dihindari. Hal ini karena di antara pelaku (actor), baik owner, pemerintah, maupun rakyat-memiliki peluang untuk menerjemahkan, mendesakkan, bahkan memaksakan keinginan guna mencapai tujuan (goal) berdasarkan atas nilai-nilai, pengetahuan-pengetahuan, motif-motif, dan 
tujuan-tujuan tertentu maupun situasi tertentu. Sedang dalam sisi lain - para pelaku juga memiliki potensi untuk merumuskan kembali "tujuan bersama".

\section{Simpulan}

Dari serangkaian uraian di atas, pada akhirnya bermuara kepada hal-hal berikut. Pertama, Indonesia yang konon memiliki kekayaan sumber daya alam yang luar biasa, tetapi kekayaan yang melimpah itu ternyata - hingga kini - belum bisa memakmurkan penduduknya secara merata, bahkan masih terlalu banyak penduduknya yang miskin. Kedua, masih banyaknya penduduk Indonesia yang miskin, di samping jumlah penduduk yang besar yang tidak terimbangi oleh kapasitas pendidikan (intelektualitas, sikap mental inovatif) yang mewadahi, juga karena masih banyak pejabat yang tidak capable di bidangnya dan tidak amanah, sementara elite politik masih banyak yang berantem sendiri sehingga melupakan arti kehadirannya untuk proaktif berjuang sepenuh hati untuk memakmurkan rakyatnya. Kata "memakmurkan" masih terasa sebagai sebatas jargon, dan belum menjadi roh di balik modal politik yang disandangnya. Ketiga, lembaga pendidikan dan kaum terdidik seperti mahasiswa, perlu berperan sebagai inspirator dan motivator untuk pembangunan. Bukan sebaliknya, menjadi penghambat pembangunan. Mengapa? Karena kita tahu bahwa sebaik-baiknya orang ialah yang mau dan bersedia mengabdikan ilmunya itu untuk mencapai kebaikan bersama. Jadi, kita tidak cukup hanya menjadi orang baik tanpa kita bisa menghadirkan kebaikan itu kepada lingkungan kita sendiri. Think globally, act locally.

\section{Daftar Pustaka}

Huntington, Samuel P. 2006. "Budaya Punya Andil", dalam Kebangkitan Peran Budaya. (Harrison, L.E \& Huntington, S.P. eds). Jakarta: LP3ES. Hlm. Xiii xviii.

Landes, David. 2006. "Hampir Semua Perbedaan Datang dari Budaya", dalam Harrison, L.E \& Huntington, S.P (eds) hlm: 27 - 43).

Porter, Micahael E. 2006. "Sikap, Nilai, Kepercayaan, dan Makroekonomi Kemakmuran", dalam Harrison, L.E \& Huntington, S.P (eds) hlm: 44 - 64.

Suparlan, Parsudi. 1986. "Kebudayaan dan Pembangunan”, dalam MEDIA IKA, no. 14, th 11 , Hlm. $106-135$. 